\title{
INDIVIDUALISMO ROMÂNTICO E MODERNIDADE DEMOCRÁTICA: UMA CONFIGURAÇÃO MÚTUA
}

\author{
Rosmália Ferrreira Santos
}

\begin{abstract}
RESUMO
Este artigo propõe como objeto de análise a formação de uma concepção moderna de democracia no século XIX e as relações que essa concepção guarda com a afirmação de um novo paradigma de individualismo que chamo de individualismo romântico. Minha tese é de que esses dois eventos são mutuamente configuradores, ou seja, de que a conformação de novas instituições e de uma teoria moderna da democracia guardam intimas relações com os pressupostos do novo paradigma de individualismo. O texto começa delimitando um terreno em que podemos lidar com a idéia de uma teoria homogênea da democracia ou de romantismo, investigando, em seguida, as condições em que é possível falar de individualismo propriamente romântico e da forma como essa noção é incorporada nos discursos dos democratas liberais como Stuart Mill, Tocqueville e Schumpeter.
\end{abstract}

PALAVRAS-CHAVE: individualismo; subjetividade; democracia; romantismo; Ilustração; liberdade; razão; impulsos; auto-expressão.

\begin{abstract}
"Jamais havia dançado tão deliciosamente; seus pés doíam como se facas afiadas estivessem atravessando-os, mas ela nada sentia, pois dor maior era a dor do seu coração, e, afinal, ela sabia que era a sua última noite. Era a última noite que podia ver aquele por quem deixara seu mundo, por quem sacrificara sua voz, por quem sofrera tantas torturas sem que ele sequer suspeitasse disso. Era a última noite em que respirava o mesmo ar que ele, que via o mar profundo, o céu estrelado; era uma noite eterna, sem esperanças e sem sonhos. Ela que não tinha alma e que jamais teria, dançava com o pensamento voltado para a morte".
\end{abstract}

Do conto infantil A sereiazinha, de Hans Christian Andersen (1805-1875)

O objetivo deste trabalho é discorrer sobre a relação entre a afirmação do individualismo romântico e a configuração de uma concepção moderna de democracia. Minha hipótese central é que a origem de uma democracia propriamente moderna, entendida como uma forma e uma necessidade configurada para e por um tipo específico de civilização - a sociedade ocidental moderna - está inextricavelmente ligada à eclosão do movimento romântico, mais precisamente à natureza do seu individualismo, ou seja, a uma concepção singular de indivíduo desenvolvida pelos românticos ${ }^{1}$.

1 O termo "moderno" utilizado aqui não deve ser contraposto, como normalmente se faz no estudo da história, a "contemporâneo" ou a "antigo", ou seja, não deve ser visto apenas em sua feição temporal, mas, principalmente,
Um grande desafio que se apresenta quando se propõe um tema desses é enfrentar as investidas contra o que se parece uma "incomensurável ambição", dada sua inegável amplitude. Contra esses prenúncios tenho a dizer que, a despeito qualquer ceticismo, por trás de todo trabalho científico ou teórico, sempre há um apelo universalístico. Ao escolher um tema, um autor

compreendido como uma entidade analítica. Ele diz respeito à inovação do experimento político que tem lugar na modernidade, mais precisamente a partir do período que me disponho a analisar - do final do século XVIII ao século XIX - e que comumente designamos por democracia, embora alguns designem-no também por tradição do governo representativo. Não vou aqui descer ao âmago da polêmica sobre qual das denominações seria mais fiel ao caráter desse experimento. 
ou um caso para investigar, a primeira pergunta que se nos apresenta é: qual o propósito de realizar tal empreitada, muitas vezes ressuscitando personagens e eventos que existiram a seu tempo sem despertar a atenção de ninguém? Precisamente, penso, se suspeitarmos haver aí elementos que sejam relevantes para todos os viventes de determinada formação social pretérita ou presente - e que só, e somente só, podem ser vistos, esclarecidos, compreendidos, daquele ângulo e de nenhum outro mais, de tal forma que os estudar tem conseqüências para a vida, ou a forma de pensá-la, de toda uma coletividade. Nesse sentido, a ambição é um dos pilares da produção intelectual. Não há teoria sem uma pretensão mínima de generalização, não importa se tomemos como objeto de nossa investigação um tema mais abrangente ou um caso singular.

Pois bem, o romantismo não é, para mim, nem mais nem menos que um "caso". O que proponho como hipótese é que o que chamamos de "democracia" não é totalmente compreensível se não a enfocarmos do ponto de vista desse movimento que eclodia no momento de sua configuração (institucional e teórica) e que foi adotado como um ethos, no sentido mais amplo desse termo, por toda a civilização que adotou essa forma política. Isso significa que não podemos negligenciar o fato (e impressiona-me a escassez de tentativas em esclarecê-lo até o momento) de que o romantismo foi um movimento (e um momento) ímpar na história ocidental, em que todas as crenças que comporiam a mitologia da subjetividade moderna - a espontaneidade, a sensibilidade, a expressão, a fruição do mundo e, sobretudo, a sensação e fruição de si como sujeito singular, expressivo e único (e todas essas promessas miraculosas da modernidade a um indivíduo que se descobre em um mundo que lhe parece tão repleto de vida e possibilidades de auto-realização) - estão abrolhandose. A epígrafe de Andersen, acima, revela precisamente esse momento fundacional do romantismo: o maravilhar-se do contista ante um universo fictício, fantástico, fantasioso, em que os segredos da alma e da vida encontram sua expressão mais ingênua. Um universo em que, como disse Eugène de Keyser, a ironia e a ternura encontram símbolos fáceis e que agrada à civilização romântica especialmente porque "resolvia, como quem brinca, as difíceis relações do homem com o mundo" (KEYSER, 1965, p. 149).
Ora, não é possível deixar de notar que, concomitantemente a essa erupção coletiva de subjetividade, assistia-se a nascer o sistema que, pelo menos teoricamente, tinha como foco tornar a ordem política mais porosa aos apelos desse novo sujeito. Simples coincidência? Não seria o caso de se perguntar se não há aí nexos e relações insuspeitas e que atravessaram esses séculos sem receber dos estudiosos a atenção devida? O texto que segue é uma primeira tentativa de descortinar o véu que encobre esse problema.

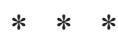

Na noite de 4 de agosto de 1789, nascia no Ocidente uma nova civilização que, como diria um crítico da arte romântica, em menos de cem anos haveria de submeter quase todos os povos e estaria a ponto de adornar-se com todas as fontes de energia e riquezas da terra (idem, p. 9). Sua revolução fôra o feito mais grandioso de uma crença deslumbrada no poder da vontade soberana, no livre discernimento, na Razão. Mas dir-se-ia ser seu último estertor. À civilização que nascia da Bastilha todos esses entes parecerão por demais longínquos, desbotados, estéreis e desgarrados do mundo mortal. A nova civilização clama por concretude, movimento, energia, vida em abundância. Ao burguês que se alçava ao poder, o homem do crédito bancário, das manufaturas - que logo se revolucionarão com a introdução de novas forças motrizes - do domínio de um sistema econômico que parecia em perpétua expansão, da ostentação até à frivolidade, da crença cega em um progresso sem limites, a vida parecia por demais rica e fluida para ser aprisionada por abstrações. Nascia no Ocidente romântico a civilização da democracia.

Não obstante, nem o Ocidente nem sua civilização, no transcurso de muitas gerações, deixaram de estar confusos sobre o significado ou a extensão do seu novo ethos. Em 1798, Friedrich Schlegel, em carta ao seu irmão August, declarava em uma dessas frases memoráveis que atravessam a história: "Minha explicação da palavra 'romantique' eu não poderia mandar-lhe, pois ela esparrama-se por 125 folhas tipográficas"2 (Schlegel apud GUSDORF, 1982, p. 17). A bela

\footnotetext{
2 "Mon explication du mot 'romantique', j'aurais de la peine a l'envoyer - car elle s'étend sur 125 feuilles d'imprimerie". A famosa frase de Schlegel é a nota de abertura do volume de quase 500 páginas sobre os
} 
retórica do jovem Schlegel tomaria um tom bem mais dramático na declaração de um dos mais eminentes teóricos da democracia do século XX, duzentos anos mais tarde: os dois milênios que transcorreram desde que a idéia e as instituições da democracia foram explicitamente desenvolvidos pelos gregos somaram enormemente para o que pode ser considerado relevante na teoria e prática da democracia, mas o que uma teoria democrática poderia razoavelmente incluir ainda permanece ignorado $^{3}$ (DAHL, 1989, p. 5-6).

Juntar o que não se define em 2000 páginas com o que não se esclareceu em 2000 anos pode ser uma tarefa muito árdua. Escorregadio, inefável, inapreensível, contraditório, o romantismo é, mais de dois séculos depois da ironia de Schlegel, um desafio à reflexão. A verdade é que o romantismo não se permitiu ser claro nem com relação à sua forma, nem com respeito ao seu conteúdo. Foi tão afim da revolução quanto da reação, serviu tanto à esquerda quanto à direita, foi apropriado por pensadores progressistas e iluminados como Stuart Mill, mas também agradou aos conservado-res e malditos. Sob essa denominação é difícil precisar o que podemos encontrar. Georges Gus-dorf (1982, p. 22-23), em seu Fondements du savoir romantique, chega mesmo a sugerir que ignora a essência do romantismo quem pretende dar-lhe "uma estrutura racional e sistemática, dotando-lhe de um programa teórico consciente" ao invés de pensá-lo como uma inspiração, o foco imaginário de irradiação de uma busca, "um fermento cultural, um tipo de sensibilidade característica da época"" Do lado da democracia, não encontramos um

Fondements du savoir romantique, que integra a coletânea Les Sciences Humaines et la Pensée Occidental (1982) de Georges Gusdorf. Um detalhe interessante: Gusdorf acrescenta em nota que a palavra alemã "Bogen", empregada por Schlegel, e que designa na Alemanha "feuilles d'imprimerie", compreende na verdade 16 páginas, o que significa que 125 folhas tipográficas corresponderiam a exatas 2000 páginas!

3 "The two millennia since the idea and institutions of democracy were explicitly developed by Greeks have added enormously to what is relevant democratic theory and practice. Yet $[\ldots]$ that a 'democratic theory' might reasonably include remains unclear” (DAHL, 1989, p. 5- 6).

4 "Une structure rationnelle et systématique, en le dotant d'un programme théorique conscient", "un ferment culturel, un type de sensibilité caractéristique de l'époque" (GUSDORF, 1982, p. 22-23). panorama muito mais favorável. A declaração de Dahl é apenas mais uma na esteira das muitas desistências em capturar-lhe o sentido preciso. Mas se vamos engajar-nos nessa tarefa - de estabelecer uma relação entre romantismo e democracia -, não podemos esquivar-nos de acercar-nos de um terreno que nos dê algum chão firme para lidar, conjuntamente, com esses dois assuntos. Comecemos por tratar da democracia.

De acordo com Dahl (1989), a democracia, assim como existe hoje no mundo, tem sido concebida de diferentes maneiras. Há os que a pensam como um conjunto distinto de instituições e práticas políticas; outros, como um corpo particular de direitos; outros, ainda, como uma ordem social e econômica; há aqueles que a concebem como um sistema que assegura certos resultados desejáveis e, finalmente, há quem a tome como um processo único de tomada de decisões coletivas e vinculantes. Não é minha intenção nesta pesquisa explorar todas essas concepções ou outras que ainda possam ser acrescentadas à lista. Meu foco será exclusivamente restrito à última delas - a democracia como processo -, que é a concepção adotada pelo próprio Dahl. Tomarei como pressuposto que muitos dos aspectos das demais concepções mencionadas são contemplados na idéia de democracia como processo de tomada de decisões e que essas concepções não são mutuamente excludentes quando interpretadas dentro de um veio doutrinário específico. Ou seja, não se trataria precisamente de concepções distintas, mas de dimensões que cada tradição tenderia a interpretar e encaminhar de determinada forma. Não se pode negar, a meu ver, que a tradição liberal contempla, a seu modo, todas essas dimensões da democracia e que possivelmente qualquer ordem que a suplante teria que reinventar a democracia a partir de um arcabouço mais ou menos semelhante. Daí que eu prefira falar em "democracia moderna" ao invés de simplesmente "democracia liberal". Mas, mesmo aqui, devo dizer que meu intento não é explorar as implicações, a operacionalidade e os limites de todas as possíveis variantes da democracia moderna. Nos limites desta proposta, basta-nos simplesmente admitir - para fins puramente heurísticos - que temos no eixo Schumpeter-Dahl (rigorosamente falando, no próprio Dahl) o ponto de culminância de uma tradição e de um modelo específico de organização política, que representa a consolidação 
final de: 1) uma concepção normativa da ordem política e 2) sua formalização em termos empíricodescritivos. Ou seja, encontramos aí a elaboração mais complexa e sofisticada de um modelo dentro de um certo veio teórico (o liberalismo), que nos permite falar de uma teoria liberal da democracia - entendendo aí toda a tradição que vem desde o século XIX e que se fundamenta nos mesmos pressupostos. É, portanto, da "moderna democracia liberal" que estou ocupando-me neste texto. Entretanto, não desenvolverei uma discussão conceitual acurada da democracia, nem traçarei seu percurso evolutivo. Para a compreensão da relação que proponho entre romantismo e democracia liberal, será suficiente aceitar como pressuposto a existência de um "cânone" que reúna certos traços comuns em distintas formas de conceber a ordem democrática moderna - independentemente das profundas diferenças que possa haver entre elas - que nos permita falar heuristicamente em teoria liberal da democracia. Como exemplo poderíamos citar o pressuposto fundamental da separação entre sociedade civil e Estado, a limitação do poder de ação deste último, a representação, o procedimentalismo e a prioritária proteção das liberdades individuais. Evidentemente que isso não esgota nem fecha a discussão do tema proposto. Mas circunscreve minhas preocupações no campo a que as estou remetendo: a existência de uma ligação entre o individualismo romântico à noção liberal moderna de indivíduo que está na base de sua teoria democrática.

Com relação ao romantismo, o caso é um pouco mais delicado. Como já mencionei, os conselhos de Gusdorf em seu Fondements du savoir romantique não são muito animadores para quem deseja apreender o significado desse movimento. Com efeito, não foi por inconsistência que o inefável romantismo esvaiu-se em direção ao intangível, mas justamente o contrário. Ponderações como a de Gusdorf enquadram-se no melhor espírito do movimento romântico. Todavia, ela parece-nos visivelmente contaminada pelo encantamento que o romantismo produz em boa parte dos seus estudiosos ${ }^{5}$. Não que eu veja grandes incon-

\footnotetext{
5 "Scholarship and critical of Romanticism and its works are dominated by a Romantic ideology, by an uncritical absorption in Romanticism's own self-representation" (MCGANN'S, 1979, p. 14-160; cf. PRIVATEER, 1991, Preface).
}

venientes em os estudiosos do movimento romântico apaixonarem-se pelo romantismo. Em boa medida isso é inevitável. O problema é que esse próprio poder de sedução do romantismo deve ser, ele mesmo, problematizado. No mínimo ele levanos a pensar que um movimento que projeta seu fascínio dois séculos além de sua eclosão não pode ser preenchido apenas de "intangibilidades". Em outras palavras, se o romantismo não possuísse mais méritos do que esse sentido do maravilhoso, do misterioso e do obscuro de que se orgulha tanto e que tantas vezes considera-se sua melhor e mais substancial característica, desde há muito já teria desaparecido (CASSIRER, 1979, p. 276).

Se não em sua substância mais pura (a opacidade, a inefabilidade), onde, então, procurar as razões dessa perduração de dois séculos do romantismo? Para Cassirer a resposta encontra-se na moderna crítica historiográfica. Ali o romantismo teria colhido seu melhor fruto, dado sua melhor contribuição às ciências do espírito. Só ali a obra edificada pelos românticos "seguia de pé com todo o seu frescor, muito depois de se haver esfumaçado o brilho e o esplendor poético, de haver murchado "a flor azul do romantismo"" (idem, p. 277). A importância dessa asserção de Cassirer é que ela abre uma senda para a busca do significado e da influência do romantismo para além dos motes com que seus criadores fizeramse autolegitimar. Essa perspectiva faz-nos ver que, por debaixo da prédica do indefinível, do inapreensível, do mutável, do indizível, o romantismo guardou em si o germe mais profundo do elemento que o plasmou e que foi profundamente alterado por ele: a Ilustração. Assim, desde o final do século XVIII já não podemos olhar as obras da Ilustração sem enxergar nelas as marcas do romantismo, como também não é possível compreender a perdurabilidade do romantismo sem atentar para a inconfessa aspiração de universalidade que lhe é imanente. É essa aspiração que os românticos grafam com mãos firmes em sua arte e em sua historiografia.

Mas não é a arte nem a historiografia romântica que nos interessam aqui, mas a influência do romantismo no campo da política. Admitida, porém, essa aspiração de universalidade, o resto fica menos difícil.

O Romantismo político de Carl Schmitt (1986) é um dos poucos trabalhos que conheço que tangencia a conexão a que aludimos no item ante- 
rior, entre romantismo e democracia. Assim como Cassirer, Schmitt empenhou-se na tarefa de alcançar o núcleo duro do romantismo. Segundo ele, é absolutamente necessário que o núcleo de um movimento intelectual seja claro para que nos seja possível pensar sobre ele. O elemento que Schmitt identifica como unificador do romantismo, seu núcleo, é o que chama de "ocasionalismo subjetificado". Ocasionalismo é uma doutrina filosófica - um sistema metafísico que, prescindindo de qualquer força ou nexo causal, toma como única base metafísica um ente absoluto e final (Deus, Estado, Nação); mas é também uma atitude. A atitude ocasionalista é aquela que toma o mundo, e tudo que nele existe, como mera ocasião, oportunidade, chance, meio para a manifestação do que é tido como a autoridade e juiz absoluto (Deus, Estado etc.) de toda ação no mundo. O romantismo é um ocasionalismo de tipo subjetificado. Nele o ente considerado absoluto é o sujeito individual. Esse argumento de Schmitt interessa-nos. Minha hipótese é precisamente que, no seu trato com o indivíduo, nessa absolutização da individualidade, o romantismo conecta-se com a moderna democracia. A questão que se impõe então deslindar é: que indivíduo e que individualidade é essa preconizada pelo romantismo e que vínculos ela guarda com a democracia? Para melhor explorar o problema, vamos persegui-lo por partes. Comecemos reformulando a primeira questão da seguinte forma: é possível identificar na história algo que poderíamos chamar de individualismo romântico, definido como um novo paradigma de individualidade?

Antes de prosseguir é preciso deixar claro que, a despeito do seu significado, o romantismo, como um movimento localizado no tempo e no espaço, restringe-se à Europa, mais precisamente à Alemanha e estende-se do final do século XVIII até por volta de meados do século XIX. Em segundo lugar, dizer que a absolutização do individualismo foi obra romântica não significa dizer que a idéia de indivíduo foi invenção, ou mesmo especialidade, dos alemães. Na verdade, tomar o individualismo como pedra angular do romantismo exige uma dedução complexa e que perfaz um caminho tortuoso. Das quatro dimensões fundamentais da noção de individualismo inventariadas por Steven Lukes (1975) - a valorização da dignidade do homem, a idéia de autonomia, a valorização da intimidade e a noção de auto-aperfeiçoamento -, algumas estão presentes na tradição filosófica alemã e no romantismo, mas nem todas. E nem todos que as adotaram foram românticos. Kant, por exemplo, a quem se atribui a elaboração da idéia de autonomia, não foi um romântico. Também Hegel e o jovem Marx ocupam uma posição ambígua nesse esquema. De acordo com Louis Dumont (1985), Hegel e Marx realizaram os mais generosos esforços de redimir os ideais da Revolução Francesa "da condenação que a história pronunciara contra eles em suas manifestações de fato" (idem, p. 117). "O socialista Marx", sentencia Dumont, "crê no Indivíduo de uma maneira que não tem precedente em Hobbes, Rousseau e Hegel, nem mesmo - diríamos - em Locke" (idem, p. 119).

Sem embargo, se não nos for possível depurar a idéia de indivíduo das inúmeras contaminações oriundas de suas diferentes fontes e abordagens algumas mesmo antagônicas -, pareceria uma tolice dizer que o individualismo romântico e a democracia liberal são mutuamente configuradores $^{6}$. As perspectivas de Lukes e de Dumont introduzidas acima oferecem uma possível saída. Se a tese de Dumont - de que Hegel e Marx reabilitaram o individualismo das funestas implicações da Revolução Francesa - estiver correta, e se conseguirmos demonstrar que só o elemento romântico na obra desses pensadores tornou isso possível, é igualmente possível demonstrar que o individualismo introduzido na moderna teoria democrática, reabilitado, não poderia ser senão romântico. Outro possível caminho seria aceitar a opção oferecida por Lukes de que aquelas quatro dimensões (a valorização da dignidade do homem, a idéia de autonomia, a valorização da intimidade e a noção de autoaperfeiçoamento) são imprescindíveis a qualquer abordagem individualista e demonstrar que pelo menos uma dela é especificamente romântica, no sentido de que não se apresentaria sem o romantismo. Isso posto, não nos seria possível escapar da conclusão de que a moderna democracia, se individualista, em alguma medida seria romântica; ou: o romantismo é uma condição necessária à configuração desse sistema.

\footnotetext{
6 Greenblatt (1984) fala-nos exatamente do processo de formação do "self" já na Renascença, a partir da experiência literária, por meio do conceito de automodelagem.
} 
Todavia, uma conexão desse tipo não deverá ser tentada aqui. O que farei a seguir será, aceitando a suposição de Dumont, explorar como a noção de individualismo liberal condenada pelos eventos da Revolução transmutou-se no que poderíamos chamar de um novo individualismo incorporando as dimensões descritas por Lukes e como o romantismo foi essencial para esse processo. Em seguida tentaremos ver como alguns pensadores liberais precursores da moderna teoria democrática, como Stuart Mill, em alguma medida Tocqueville e mesmo Schumpeter, incorporaram essa nova noção em seus discursos.

Retomemos o argumento de Steven Lukes. Ele faz uma pequena genealogia do termo "individualismo" que se mostra bastante esclarecedora da transmutação de que falei ainda há pouco. De acordo com ele, os alemães - assim como já haviam feito os franceses - cultivaram um profundo desapreço pelo individualismo atomístico da Ilustração. Mas ali, ao invés do puro rechaço, a idéia passaria por um surpreendente processo de alquimia. O modelo racionalista, universalista e uniforme do Iluminismo - que postula um indivíduo abstrato e a-histórico - foi matizado pelo conceito de criatividade e autonomia do espírito e pela idéia de progresso e auto-aperfeiçoamento individual ao longo da história. O atomismo - alvo da impiedosa crítica dos franceses - converteu-se curiosamente no seu oposto: renasceu a idéia de unicidade, de unidade orgânica entre o indivíduo, a comunidade, a sociedade, a coletividade, que é tomada como o meio de expressão, ou melhor, da auto-expressão da individualidade. Do ponto de vista da teoria política, trata-se de uma reintegração entre o indivíduo e a ordem.

Frederick Beiser (1987), que estudou detidamente o idealismo alemão, endossou esse argumento. De acordo com ele, é possível encontrar, mesmo nos primeiros escritos dos românticos, um profundo repúdio pela forma como o liberalismo clássico dicotomizava o indivíduo ao pensá-lo como um ser completo em todas as suas necessidades e desejos fora da sociedade e ao conceberem o auto-interesse como a base da ação social. Para os românticos, afirma Beiser, era inconcebível a vida do homem - cuja natureza é essencialmente social - fora dos seus laços de pertencimento à comunidade. Como resultado dessa concepção, teremos a conversão do atomismo, o "individualisme", execrado pelos franceses, no conceito de "individualidade". Os românticos podiam pensar nessa conciliação de individualidade e laços de pertencimento porque, para eles, ainda de acordo com Beiser, não haveria individualidade fora da interação com o outro. Só por meio da partilha de nós mesmos com os outros podemos desenvolver nossa individualidade única. E isso porque viver em grupo é perfeitamente natural para nós, nasce do mais profundo impulso de nossa natureza. Evidentemente, somos levados a concluir que não pode haver uma contradição entre a afirmação do $e u$ como ser único e original e sua própria natureza. Essa idéia de "único" será cara ao romantismo. Será ela o contraponto ao individualismo cego e egoísta freqüentemente mobilizado em nome do liberalismo, através da noção de irrepetibilidade, exclusividade e, ao mesmo tempo, de plenitude. Não se trata mais apenas do indivíduo abstrato e a-histórico do liberalismo e da Ilustração, que postulam uma natureza imutável e aquém dos seus valores e objetivos morais, da sua história, da sua cultura, mas de um indivíduo colado ao seu mundo, ao seu destino, que se encontra tão inteiro em suas relações com o mundo e a sociedade quanto consigo mesmo. Os românticos falarão de uma individualidade qualificada, que qualifica a existência e distingue cada homem da idéia de uma massa de partículas inconscientes; como os alemães gostavam de dizer, trata-se de um individualismo qualitativo, por oposição ao individualismo quantitativo liberal.

O indivíduo romântico parece possuir, sobretudo, uma ânsia insaciável de auto-expressão. Um outro texto de Beiser, em que trata das relações entre Kant e Hamann - que ele chama de o pai do Sturm und Drang (o marco inicial do romantismo) - fala de uma significação metafísica da autoexpressão artística que conformará toda a estética romântica posterior: uma crença em que a paixão e os sentimentos do artista são capazes de revelar a realidade em si mesma. Schleiermacher, Hölderlin, Schelling, Novalis, Schlegel, toda a geração romântica "acredita que as forças do universo revelam-se ou manifestam-se na visão pessoal do artista" (idem, p. 37) 7 . Algo semelhante disse-nos Cassirer sobre a historiografia de Ranke,

\footnotetext{
7 "Believe that the forces of the universe reveal or manifest themselves in the personal vision of the artist [...]".
} 
em que, segundo ele, "a história deve falar, por sua simples existência, pela força dos fatos e o peso das idéias" (CASSIRER, 1979, p. 283), por meio do historiador, posicionado como um espelho em que as forças espirituais e criadoras presentes na história revelam-se-nos em toda sua plasticidade. As matrizes desse individualismo expressivista parecem ser opacas. A tese de Beiser é de que sua origem é fundamentalmente cética e empirista. Hamann e toda a geração romântica que o seguiu travaram sua cruzada contra a Ilustração, baseados no reconhecimento da ignorância e nos limites e na incapacidade da razão em demonstrar a existência, ou a inexistência, de qualquer coisa. Em uma de suas querelas com Kant, Hamann têlo-ia, inclusive, induzido ao contato com Hume. Mas a negação da autoridade da razão não implica a legitimação de qualquer outra faculdade no ato de conhecer. De modo que, para tornar plausível sua causa - ainda mais contra o "majestoso" Kant (no caso de Hamann e da defesa da fé luterana) seria necessário um elemento assertivo, ou positivo, como o chamará Beiser. Esse elemento será, para Hamann, "um tipo particular de experiência", que ele chamará de "sensação". A sensação não tem a ver com o objetivismo dos sentidos, mas com uma certa experiência inefável. A sensação da fé, por exemplo, é a experiência que chega diante da confrontação com a incompreensibilidade e a absurdidade da vida e da morte. Penso que a noção de "sensação" é uma novidade. Ela traduz a experiência sensorial diante do intangível - o mistério da vida e da morte -; é a experiência vivida pelo espírito, pela alma, a experiência por excelência do sujeito. Se a fonte inspiradora desse subjetivismo foi o desencantamento da razão e de sua capacidade de resolver os enigmas da vida, o recurso ao empiroceticismo, certamente, não foi sua base. Suas raízes, creio, devem ser buscadas em sua relação com a mística do luteranismo (GABÁS, 1969, p. 33-34).

A filosofia alemã, desde Kant, e mais acentuadamente no período idealista clássico, teve uma íntima ligação com os elementos místicos da reforma luterana. Foram os pietistas os primeiros a insistir nos aspectos subjetivos da persuasão teológica, desenvolvendo a idéia de que a graça divina é algo íntimo, revelado pela experiência pessoal do fiel com Deus. Podemos atestá-lo na influência que o místico luterano Jakob Böhme exerceu sobre o pensamento idealista de Fichte,
Schelling e Hegel. A teologia de Böhme dá plena vazão a especulações de tipo subjetivista. Ela apóia-se no pretenso sentido oculto das Escrituras, transmitido por revelação direta de Deus ao homem, e em uma troca solitária do sujeito com Ele (idem, p. 321-329). Daí um certo processo de imanentização da mística de que nos fala o filósofo jesuíta Henrique de Lima Vaz e que figura como uma linha que se prolonga no romantismo alemão, na "vizinhança dos grandes sistemas idealistas", cuja culminância deu-se com Hegel (VAZ, 1994, p. 33). Ali, "a primazia do sujeito impõe suas exigências em face da transcendência metafísica do Ser" (idem, p. 34). As categorias da mística foram dessacralizadas e secularizadas e deram origem a um processo de rechaço ao Absoluto transcendental - situado além do mundo concreto -, transposto para o mundo histórico. $\mathrm{O}$ alvo da mística "deixa de ser a profundidade insondável do Deus transcendente e é posto na história ou, mais exatamente, na práxis histórica do homem" (ibidem). Nesse processo, prossegue o filósofo jesuíta, a mística especulativa - que objetiva investigar por meio das categorias do pensamento o mistério do Absoluto - transmuta-se na metafísica da subjetividade. Ou na absolutização do $e u$, porém não mais voltado para a fruição do transcendente, mas do imanente, do mundo humano, histórico. Em suma, o romantismo em seu ser mais profundo é afim à mística e adversário natural da Ilustração; a ironia do espírito que reflete sobre si mesmo já não se dirige para Deus, mas contra o ridículo de um mundo sem Deus e sem espírito (HARTMANN, 1960, p. 249-250).

Do que foi dito acima, somos induzidos a duas hipóteses: primeiro, o subjetivismo sensorial e expressivista que se decantava na arte romântica era o substrato do seu individualismo. Segundo, o subjetivismo sensorial como substrato do individualismo parece ser uma formidável inovação. O que é novo aqui não é a percepção, ou a experiência, da subjetividade. O que é novo é postulação da interioridade - "inwardness" como um ideal ético, moral e estético - no limite, como um programa filosófico. Mas inwardness é agora, acima de tudo, uma exigência do espírito que age no mundo. A vida e a morte esgotam-se na caverna, a filosofia e o homem estão igualmente imersos na escuridão da profundidade insondável do ser imanente. A filosofia decididamente perdeu o céu de Platão, mas encarnou-se no mundo dos homens, ganhou a terra. 
Todavia, não podemos deixar de notar que essa nova exigência do espírito parece uma meta contraditória. Como nos mostra Beiser, ela resulta da fusão de um extremo subjetivismo, que exige que o artista, ou o historiador, expresse seus mais íntimos desejos e sentimentos, e um extremo objetivismo, que demanda que ele imite estritamente a natureza, ou os fatos, e entregue-se aos seus efeitos sobre ele - seja seu espelho. Penso que essa tensão entre a fruição da experiência sensorial e, ao mesmo tempo, a rendição ao mundo objetivo será um dos pontos mais significativos da conexão que perseguimos entre o romantismo e as instituições liberais burguesas do século XIX, incluindo aí suas instituições políticas. Parafraseando Eugène de Keyser, até o dia em que se puseram a celebrar a liberdade, jamais se havia construído tão grandes quartéis nem tão imensas prisões; eles representam os símbolos ambíguos de uma época em que são proclamados os direitos do homem, mas em que triunfa a força (KEYSER, 1965, p. 47). Com efeito, a aclamação do ímpeto, da expressão, dos desejos irrefreáveis e cambiantes com suas inclinações, afetos, paixões, enfim, suas exigências sensíveis, parece a agenda ética sob medida para uma civilização que construiu seu reino neste mundo. O burguês é romântico, por condição. "Não canta acaso a liberdade, a vida em crescimento, o perpétuo porvir?". O poeta, como o burguês, fala a mesma linguagem política (idem, p. 33). A conjugação dessa agenda ética liberal-fruitiva com os ambíguos signos da força de que nos falava Kayser ainda há pouco parece uma nítida expressão da contraditória meta do espírito romântico, dividido entre o abandono à experiência sensorial do sujeito e os imperativos de rendição ao mundo objetivo e suas códigos restritivos. Este será, sem dúvida, um dos paradoxos da moderna democracia liberal.

A verdade é que, se há algo que os liberais do novecentos não duvidavam, era de que sua linguagem política, romântica ou não, era eminentemente nova. Pelo menos desde Benjamin Constant, em 1819, sempre se acreditou que a liberdade antiga não serviria aos modernos. E não serve porque este é um homem novo, cuja fruição da individualidade conta acima do político, acima do público. A liberdade de que precisamos é diferente da dos antigos, dizia Constant, e necessita de uma organização diferente da que poderia convir aos antigos (CONSTANT, 1980, p. 23). A intuição de Constant é magnífica, pois captava em um lampejo o espírito preciso que orientaria os construtores do regime democrático. Constant sabia que a individualidade do novo homem deveria contar acima do público, mas não acima da ordem. A liberdade dos antigos permitia-lhes a vida pública porque suas paixões individuais eram privadas e, enquanto assim fosse, a ordem estaria garantida. No individualismo romântico as paixões reivindicam, sobretudo, publicização e legitimidade. $\mathrm{O}$ público já não pode ignorá-las. Aliás, os liberais já sabiam disso desde Hobbes. A novidade agora é que o público necessita regular e delimitar o espaço das paixões - ou teremos o caos - mas não é mais possível suprimi-las por força alguma. Elas explodem por todos os poros da vida burguesa. E mais: dizer que o poeta e o político burguês falam a mesma linguagem romântica significa dizer também que há em ambos um anseio comum: a fruição da sua nova liberdade. Talvez seja por isso que Constant a um tempo canta a liberdade e a outro a organização do seu tempo.

Essa ambigüidade é ainda mais notória em Stuart Mill, que foi mais longe do que qualquer outro liberal do seu tempo na afirmação do novo individualismo. Ele afirmou que os desejos e impulsos são tão parte de um ser humano perfeito quanto crenças e restrições e que os impulsos fortes só são perigosos quando não são devidamente equilibrados (MILL, 1989, p. 60). A influência romântica sobre Mill é explícita e confessa. Citando Humboldt, ele assegura que a meta humana, por excelência, é o autoaperfeiçoamento individual. Em princípio, Mill não vê uma incompatibilidade da afirmação irrestrita dos impulsos espontâneos, do cultivo da individualidade, com a ordem (desde que freados por uma consciência suficientemente forte): não é porque os desejos dos homens são fortes que eles agem mal, mas porque sua consciência é fraca, afirma Mill (ibidem $)^{8}$; mas o importante é observar que isso não guarda especial relação com nenhuma forma de governar. Mesmo o despotismo não produz seus piores efeitos desde que a individualidade exista sob ele. Mas, ao contrário, o que quer que esmague a individualidade é despotismo, seja por qual nome atenda, ou qual a

\footnotetext{
8 "It is not because men' $s$ desires are strong that they act ill; it is because their consciences are weak".
} 
fonte de sua legitimidade: a vontade de Deus ou injunção dos homens. Ao que parece, temos aqui um claro recado à democracia em nome do individualismo romântico. Mas, alguns séculos antes da explosão do ethos romântico, esse argumento já fôra proferido por Hobbes. A alegação era de que a fonte da liberdade importa menos que sua extensão; os súditos de um regime despótico podem ter tanta liberdade privada quanto um cidadão da mais promissora democracia (SKINNER, 1999, p. 73). A questão é que a liberdade privada de Hobbes dificilmente incluiria a livre expressão dos desejos e impulsos fortes, como recomenda Mill. Além disso, em um contexto de afirmação do cultivo da individualidade - em que, como afirma Mill, as faculdades de percepção, julgamento, discriminação, atividade mental e preferência moral são exercitadas somente por meio da liberdade de escolha (MILL, 1989, p. 59) -, é difícil não vir à tona o problema do autogoverno. Da democracia.

A reabilitação alemã do individualismo, para continuar na linha argumentativa da tese de Dumont, parece colher agora seu fruto mais maduro. O ideal da autonomia é recolocado em pauta no plano da política. Mas a sombra do radicalismo da Revolução ainda estava suficientemente próxima para toldar as esperanças democráticas. O ideal de autonomia não poderia ser reposto no mundo da polis sem as ressalvas conservadoras. É aqui que se fazem ouvir os ecos de um discurso que perdurará por muito tempo e que expressa o terror ainda fresco da experiência da Revolução: o governo do povo só se dará despoticamente e pelos pobres. A idéia de uma "tirania de maioria" tornou-se o tom oficial, quase uma obsessão, de todos os discursos liberais. O governo do povo não é o governo de cada um sobre si mesmo, dirá Mill, mas o governo de cada um sobre os demais. E a vontade do povo não é senão a vontade do maior número, da maioria, e a maioria pode desejar oprimir uma parte de si mesma. Precauções são tão necessárias contra isso, brada Mill, quanto contra qualquer tipo de abuso de poder. E quem é o povo, senão a massa inculta, a mediocridade coletiva? Eles não formam sua opinião a partir de autoridades da Igreja, do Estado, de líderes cultivados, ou dos livros, mas do pensamento de homens iguais a eles próprios, insiste Mill admirado. Dessa forma, a democracia como governo do povo só poderá ser o governo da mediocridade, a menos que o povo seja guiado por "um" ou por "uns poucos" agraciados e instruídos. Aqui a celebração da individualidade tinge-se de um negro conservadorismo. Essa intuição de Mill só será, contudo, plena e cruamente enunciada 100 anos depois, com Joseph Schumpeter.

A base do argumento de Schumpeter será o mesmo individualismo radical, mas agora naturalizado, axiomático. Schumpeter reconheceu, como Stuart Mill, que não é possível formar nenhuma vontade do povo, pois o povo, composto de indivíduos, tem sua vontade extremamente dividida e a vontade do indivíduo simplesmente não existe, ou não pode ser racionalmente organizada. $\mathrm{O}$ mundo individual é formado por forças absolutamente irracionais e dinâmicas (desejos e impulsos fortes), não há qualquer unidade da consciência, não existe um "eu" independente capaz de guiar-se pelos discernimentos da própria razão. $\mathrm{O}$ espaço para a manifestação inócua dessa irracionalidade é o privado. Se os condicionantes morais e o treino técnico permitem ao indivíduo comum orientarse com competência e moderação no plano particular, o mesmo não se dá na esfera política, em que tenderia a guiar-se por seus impulsos obscuros, irracionais ou extra-racionais. O cidadão comum, afirmava Schumpeter, o indivíduo, não tem competência para atuar no campo político, em que desce para um nível mental inferior àquele dedicado a seus negócios particulares, mesmo infantil. "Torna-se primitivo novamente. $\mathrm{O}$ seu pensamento assume o caráter puramente associativo e afetivo" (SCHUMPETER, 1961, p. 319). A conclusão de Schumpeter é a mesma de Mill: o papel do povo deve ser restrito à formação do governo e sua substituição de tempos em tempos. Há, evidentemente, uma considerável diferença entre o elitismo profissionalizante de Schumpeter (em tese aberto à competição) e o elitismo aristocrático de Mill. Mas a lógica é a mesma: o método democrático não garante necessariamente maior liberdade individual do que qualquer outro método em circunstâncias semelhantes (idem, p. 330). E por esse caminho retornamos a Hobbes.

Até aqui já nos parece suficientemente claro pelo menos um dilema da moderna teoria democrática: conciliar o individualismo imanentista romântico com a ordem, pensada a 
partir dos pressupostos racionalistas da Ilustração. $\mathrm{Ou}$ seja, a razão de indivíduos agora saudavelmente irracionais, continua sendo o fundamento da ordem política. Na fase romântica do individualismo, os impulsos irracionais não são um obstáculo à ordem, mas um componente intrínseco dela. A ordem política, contudo pensada agora para esse indivíduo -, tem ainda como pressuposto o individualismo iluminista, em que a razão é o fundamento. Ou seja, há uma esquizofrenia imanente à ordem democrática moderna que acomoda dois precipícios contraditórios dentro de um mesmo fundamento individualista. Sem embargo, perseguir a conexão entre individualismo romântico e democracia por essa via talvez soe enganador. Primeiro, porque ela não revela nenhuma causalidade necessária entre esses dois eventos. Como vimos, de Hobbes a Schumpeter vigorou a crença comum de que liberdade individual e regime político não guardam relações intrínsecas. Desde que a irracionalidade seja mantida longe do domínio público, ela não invalida o pacto. O problema trazido pelo romantismo é que a irracionalidade não pode ser mantida completamente longe do domínio político, ela requer auto-expressão pública. Mas autoexpressão não precisa significar necessariamente autogoverno. Pessoas podem viver bem, fruir e desenvolver sua individualidade plenamente sem participar da política ou do governo. Onde, então, a democracia entra nessa história?

Evidentemente, não é lógica nem historicamente plausível pensar em uma inclinação espontânea, uma boa-vontade, de a burguesia, uma vez no poder, partilhá-lo com os demais. Não bastasse o discurso da tirania da maioria para corroborar essa suposição, poderíamos inferi-la do fato de que "ficou a cargo, em grande medida, das extensas e violentamente reprimidas lutas das classes trabalhadoras e atividades feministas dos séculos dezenove e vinte atingir, em alguns países, o sufrágio genuinamente universal" (HELD, 1987, p. 65). Ou seja, a aplicação dos princípios democráticos só se deu por força de obrigar as democracias liberais a assumir as conseqüências e implicações do seu discurso. Consideradas as coisas deste ângulo, tudo que podemos concluir é que os pressupostos do novo individualismo levaram a uma crescente e irreprimível pressão pelo autogoverno.

Não obstante, a análise dos argumentos de Mill não nos autoriza a simplificar as coisas dessa maneira, pelo menos por dois motivos: primeiro, a democracia moderna não se assenta somente no princípio do autogoverno, mas também na dimensão dos direitos e esse é um traço que lhe é peculiar e fundamental. Segundo, pensar que se tratava de uma pressão externa, de ideais e idéias que se formaram à revelia dos anseios burgueses, não faz jus à euforia com que a nova liberdade (a liberdade do indivíduo) foi aclamada pelos próprios burgueses. O mais plausível seria talvez pensar que a configuração do novo regime foi uma conseqüência inescapável de suas opções morais e estéticas. Ou seja, pela adoção espontânea do ethos romântico.

A percepção mais genial, quase clarividente, a esse respeito é a de Alexis de Tocqueville. Tocqueville percebeu que a burguesia não podia fazer parar o fluxo da sua criação. A Revolução não podia ser estanque. $\mathrm{O}$ individualismo é de origem democrática, denuncia Tocqueville, e ameaça desenvolver-se à medida que as condições igualam-se. À primeira vista, Tocqueville propunha uma inversão do nosso problema. A democracia carrega consigo o germe do individualismo, já que, ao destruir os laços de hierarquia e lealdade, "traz cada um de volta a si mesmo e ameaça encerrá-lo, enfim, na solidão do seu próprio coração" (TOCQUEVILLE, 1979, p. 286). Mas, se reparamos um pouco mais detidamente, vemos que não é muito fácil detectar a direção da causalidade quando um pouco mais adiante Tocqueville asseverava-nos: se os homens que vivem em países democráticos não tivessem o direito nem o gosto de unir-se com fins políticos, sua independência correria graves riscos. Um povo em que os particulares perdessem o poder de fazer isoladamente grandes coisas, sem adquirir a faculdade de produzi-las em comum, retornaria à barbárie (idem, p. 288).

Parece claro que Tocqueville não compreendia a democracia como seus contemporâneos - uma forma de governo -, mas como uma ampla e inexorável revolução social. Mas não se mostra suficientemente claro a respeito de se a democracia é uma exigência da fraqueza resultante do individualismo ou se o individualismo é uma conseqüência inevitável da democratização. De todo modo, não é fácil escapar de uma visão mutuamente configuradora desses dois eventos a partir dessa asserção tocquevilleana. Tocqueville também parecia cônscio do paradoxo que essa mútua configuração encerra. A fraqueza 
e a incapacidade produzida pelo individualismo requereria, na opinião dos seus contemporâneos, tornar o governo "mais hábil e ativo", ou seja, mais enérgico. Mas qual o sentido dessa energia? É senso comum na tradição liberal que nenhum governo prescinde da força. E não seria despropósito dizer que ela cresce na proporção direta do espaço que é conferido à auto-expressão. Ou seja, tanto maior a capacidade de expressão dos impulsos fortes, mais debilitados os homens para defenderem sozinhos a esfera de sua autonomia. Isto é, o individualismo torna os homens desprotegidos de si próprios. Mas esse é também o argumento hobbesiano clássico. E, mais uma vez, a clássica oposição entre individualidade e ordem, entre pulsões e razão, entre o Sturm und Drang e Kant. A única luz nova que Tocqueville lança sobre nossa questão é a de que a democracia é algo inevitável, algo sem o que "a própria civilização correria perigo" e que ela está inextricavelmente ligada à individualização. Se nossa hipótese de que o individualismo que conhecemos é romântico mantém-se, não há como evitar, se não um nexo de causalidade, ao menos uma íntima relação entre ele e esta inevitabilidade da democracia relação que ainda carece de ser desvendada. Todo o resto são brumas. Indubitavelmente a moderna democracia parece ter-se formado no âmago de uma, ou de várias, tensões que se perpetuaram em toda a sua história e manifestam-se em algumas de suas conhecidas aporias; não é mais novidade que a base de tais aporias foi a incorporação de metas contraditórias. Mas, por que precisamente a democracia liberal veio ao mundo e obrigou-se a incorporar tais metas; quais as suas verdadeiras origens; por que os arquitetos do novo regime - Madison, Mill, Tocqueville, Schumpeter, para citar alguns - foram homens especialmente incrédulos ou desafeiçoados das vantagens da soberania popular; que elementos explicam o seu distintivo traço de demofobia; ou, ainda, por que um regime configurado sob o signo da fluidez, do dinamismo e do movimento mostrou-se uma forma tão dura e compacta de controle, são perguntas que se perdem nestas brumas, nas "sombras da teoria democrática", para utilizar um termo do grande sistematizador desse modelo (DAHL, 1989, p. 3). Eu tendo a crer que parte dessas sombras faz parte do mito. Isto é, nem tudo é obscuridade se falamos de democracia moderna como uma forma de organização configurada para as necessidades de um tipo específico de civilização, e moderna no sentido de que tem natureza distinta da democracia clássica, que é outro evento histórico, e que poderia muito bem levar outro nome. No entanto, isso constitui parte do problema, já que os próprios liberais são ambíguos a esse respeito. Algumas vezes fazem-nos crer que se trata de um evento novo no tempo, outras que suas inconsistências devem-se às suas múltiplas fontes e metas valorativas, adquiridas ao longo de milênios ${ }^{9}$. De todo modo, não me parece insensato pensar que houve um momento na história em que um ímpeto, se não revolucionário, ao menos de ameaçadora inquietação, perpassou toda a sociedade ocidental e forçou a disposição para a criação de formas institucionais mais afinadas com esse espírito, ou que houve uma percepção difusa por parte das elites dirigentes ocidentais de uma inquietação febril, uma subjetividade dinâmica que ansiava por ganhar a rua, um impulso vital irreprimível que não mais se podia conter nos estreitos limites do mundo privado e que esse espírito de inquietude foi trazido pelo romantismo na forma de um novo paradigma de individualismo. Seria a estreita concepção de democracia liberal uma capitulação da razão ilustrada à lógica do romantismo, a admissão cabal e definitiva de que há um mundo fora de controle para além do terreiro do Estado e que tudo de melhor que podemos fazer por ele é deixá-lo viver e morrer por si mesmo?

Para concluir, devo dizer que este é necessariamente um trabalho em aberto. Sua motivação fundamental foi a de insistir na necessidade de elucidação de questões que possibilitem explicitar, com repetida ênfase, certos paradoxos que se encontram na raiz da concepção

\footnotetext{
9 Um exemplo dessa ambigüidade é a própria idéia de uma democracia moderna como um amálgama de experiências milenares (DAHL, 1989, p. 13), ou, ainda, como uma "novidade" formada a partir do enriquecimento e da articulação das metas valorativas do cristianismo, da Reforma, do jusnaturalismo e do liberalismo (SARTORI, 1988, p. 344). Ora, ou bem a democracia é uma novidade - é moderna - ou bem a democracia é a democracia e, nesse caso, bem poderia dispensar não só a qualificação moderna como a elaboração de uma teoria específica. Afinal, que necessidade teria um regime que atravessou milênios, incorporou inúmeras práticas, ideais e noções singulares sob um mesmo conceito e uma mesma denominação de ver esse conceito e essa denominação tão arbitrariamente alterados?
} 
de ordem política moderna e que se tornam de capital importância diante da aparente crise de legitimidade que parece sufocar nossos sistemas políticos - especialmente aqueles em que a democracia veio a tornar-se uma idéia hegemônica. Um problema especialmente relevante nesse contexto é aquele levantado por algumas vertentes da democracia contemporânea: o da participação política. Apesar dos formidáveis estudos sobre a questão, a indiferença a que ainda assistimos por parte dos cidadãos para com a atividade política, ou mesmo a indigência das formas institucionais da participação, impõe-nos aprofundar a investigação dos matizes mais sutis da legitimação política. Mas a conexão aqui pretendida é demasiado complexa para ser esgotada em tão poucas páginas. Como foi dito, o romantismo foi um movimento de tendências díspares e não resulta difícil relacioná-lo com o que quer que seja. A ligação com a democracia aqui proposta funda-se em uma forte suspeição e em uma variada gama de estudos. Ainda assim, devo dizer, trata-se de uma investigação em curso e que não pretende dar conta de todos os impasses, aporias, paradoxos e inconsistências dos regimes políticos modernos. Sua importância e originalidade funda-se na suspeição de que por trás da salutar apatia que muitas vezes imputamos aos cidadãos encontrase também uma notória incapacidade das instituições políticas de forjarem mecanismos capazes de apreender o fluxo das motivações subjetivas, uma inabilidade da teoria política em correlacionar positivamente estas motivações e a atividade política, e uma desistência de ambas em apreender o indivíduo em sua inesgotável complexidade espiritual. Tais questões revelam uma lacuna na compreensão das origens conceituais da idéia de democracia moderna e a cujo respeito, espero, este trabalho contribua para chamar a atenção.

Rosmália Ferrreira Santos (rhosinha@yahoo.com.br) é Doutoranda em Ciência Política no Instituto Universitário de Pesquisas do Rio de Janeiro (IUPERJ).

\section{REFERÊNCIAS BIBLIOGRÁFICAS}

BEISER, F. C. 1987. The Fate of Reason. Cambridge, Mass. : Harvard University.

1996. The Early Political Writings of the German Romantics. Cambridge : Cambridge University.

ВОВВIO, N. 1984. Direito e Estado no pensamento de Emanuel Kant. Brasília : UNB.

.1986. O futuro da democracia : uma defesa das regras do jogo. Rio de Janeiro : Paz e Terra.

CASSIRER, E. 1943. Filosofia de la Ilustración. Pánuco : Fondo de Cultura Económica.

1979. El romantismo y los comienzos de la historigrafía crítica. In : El problema del conocimiento en la Filosofia y en la ciencia modernas. Ciudad de México : Fondo de Cultura Económica.

CONSTANT, B. 1980. De la liberté chez les modernes : écrits politiques. Paris : Hachette.

DAHL, R. A. 1956. A Preface to Democratic Theory. Chicago : University of Chicago.
1989. Democracy and its Critics. New Haven : Yale University.

DUMONT, L. 1985. O individualismo : uma perspectiva antropológica da ideologia moderna. Rio de Janeiro : Rocco.

GABÁS, R. 1969. La espiritualidad luterana. In : Historia de la espiritualidad: espiritualidades cristianas no catolicas. V. 3. Barcelona: J. Flors.

GREENBLATT, S. J. 1984. Renaissance Selffashioning : From More to Shakespeare. Chicago : University of Chicago.

GUSDORF, G. 1982. Fondements du savoir romantique. In: . Les Sciences Humaines et la pensée occidentale. Paris : Payot.

HAMILTON, A.; MADISON, T. \& JAY, J. 1979. $O$ federalista. São Paulo : Abril Cultural.

HARTMANN, N. 1960. La filosofia del idealismo alemán : Fichte, Scheling y los románticos. V. I. Buenos Aires : Sudamericana. 
HELD, D. 1987. Modelos de democracia. Belo Horizonte : Paidéia.

HOBBES, T. 1979. O leviatã ou matéria,forma e poder de um Estado eclesiástico e civil. São Paulo : Abril Cultural.

KANT, I. 1980. Fundamentação da metafisicica dos costumes. $2^{\text {a }}$ ed. São Paulo: Abril Cultural.

1988. À paz perpétua e outros opúsculos. Lisboa : ed. 70.

KEYSER, E. 1965. El Occidente romántico. Barcelona : Carroggio.

LUKES, S. 1975. El individualismo. Barcelona : Península.

MACPHERSON, C. B. 1979. A teoria do individualismo possessivo de Hobbes até Locke. Rio de Janeiro : Paz e Terra.

MARX, K. 1972. Crítica da Filosofia do Direito de Hegel. $2^{\mathrm{a}}$ ed. Lisboa : Presença.

MCGANN'S, J. 1979. What is an Author? In : HARARI, J. V. (ed.). Textual Strategies : Perspectives in Structuratist Criticism. Ithaca : Cornell University.

MILL, J. S. 1989. On Liberty. In : . On $\mathrm{Li}$ berty and Other Writings. Cambridge : Cambridge University.
PRIVATEER, P. M. 1991. Romantic Voices : Identity and Ideology in British Poetry. Athens : Georgia Universty.

ROUSSEAU, J.-J. 1978a. Discurso sobre a origem e os fundamentos da desigualdade entre os homens. São Paulo : Abril Cultural.

.1978b. Do contrato social. São Paulo : Abril Cultural.

SARTORI, G. 1988. Teoría de la democracia. Madrid : Alianza.

SCHMITT, C. 1986. Political Romanticism. Cambridge, Mass. : Massachusetts Institute of Technology.

SCHUMPETER, J. A. 1961. Capitalismo, Socialismo e Democracia. Rio de Janeiro : Fundo de Cultura.

SKINNER, Q. 1999. A liberdade antes do liberalismo. São Paulo : UNESP.

TOCQUEVILLE, A. 1979. A democracia na América. São Paulo : Abril.

TUCKER, D. F. B. 1983. Marxismo e individualismo. Rio de Janeiro : Zahar.

VAZ, H. C. L. 1994. Mística e política : a experiência mística na tradição ocidental. In : BINGEMER, M. C. L. \& BARTOLO JR., R. S. (orgs.). Mística e política. São Paulo : Loyola. 